\title{
PENGGUNAAN USER CENTERED DESIGN DALAM PEMBUATAN WEBSITE PORTAL MGBK SMA KOTA MALANG
}

\author{
Hilman Nuril Hadi'), Arif Tirtana ${ }^{2)}$, Adnan Zulkarnain ${ }^{3)}$ \\ ${ }^{1,2}$ Program Studi Teknik Informatika, STIKI Malang \\ ${ }^{3}$ Program Studi Sistem Informasi, STIKI Malang \\ ${ }_{1,2,3} \mathrm{Jl}$. Raya Tidar 100, Malang

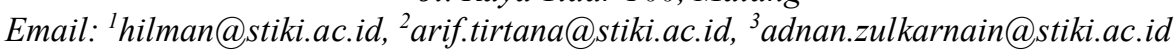

\begin{abstract}
Technology developments that have entered the Society 5.0 era encourage organizations to accelerate the digital transformation process, also encourage MGBK SMA Malang City to develop a website portal to facilitate the organization's business processes in providing a broad impact on the organization. However, the obstacle that often arises in making websites is the incompatibility of the interface with the wishes of the user. Therefore, this study using a usercentered design method to suit the needs of users and organizations. This study indicates that the use of user-centered design methods serves to improve the fit between user needs and the organization's business processes.
\end{abstract}

Keyword: User Centered Design, Website, Portal, User Experience, User Interface

\begin{abstract}
Abstrak
Perkembangan teknologi memasuki era Society 5.0 mendorong organisasi untuk mempercepat proses transformasi digital, hal tersebut juga mendorok MGBK SMA Kota Malang untuk menyusun sebuah portal website untuk memudahkan proses bisnis organisasi dalam memberikan dampak yang luas pada organisasi. Namun kendala yang sering muncul dalam pembuatan website adalah ketidaksesuaian antarmuka dengan keinginan pengguna. Oleh karena itu dalam penelitian ini menggunakan metode user centered design untuk menyesuaikan antara kebutuhan pengguna dan organisasi. Hasil dari penelitian ini menunjukkan bahwa dengan menggunakan metode user centered design berfungsi untuk meningkatkan kesesuaian antara kebutuhan pengguna dan proses bisnis organisasi
\end{abstract}

Kata Kunci: User Centered Design, Website, Portal, User Experience, User Interface

\section{Pendahuluan}

Perkembangan era Society 5.0 ini mendorong manusia untuk menggunakan aspek teknologi dalam menunjang setiap kegiatannya [1]. Hal tersebut mendorong organisasi untuk mempercepat proses transformasi digital untuk menyesuaikan dengan kebutuhan pelanggan [2]. Transformasi digital merupakan proses dan penerapan strategi dengan menggunakan teknologi informasi untuk dapat merubah proses bisnis organisasi dengan harapan dapat meningkatkan efisiensi dan efektivitas organisasi guna memberikan nilai lebih kepada pelanggan [3]. Ada beberapa aspek untuk menunjang implementasi transformasi digital berhasil diterapkan dalam sebuah organisasi, yaitu orang, bisnis, dan teknologi [4]. Dari aspek teknologi ada banyak teknologi yang dapat diterapkan untuk mempercepat transformasi digital, seperti e-commerce untuk memudahkan proses jual beli produk [5], maupun teknologi yang lain. Namun apabila organisasi ingin meningkatkan kesadaran masyarakat terkait organisasi dan mempermudah pengguna dalam mengakses informasi terkait organisasi, maka organisasi dapat menerapkan portal website [6].

Portal website merupakan salah satu media masa yang memiliki peran penting dalam menyebarkan informasi [7]. Namun terdapat permasalahan yang sering terjadi dalam penerapan portal website dalam sebuah organisasi, seringkali organisasi hanya berfokus pada tujuan bisnisnya saja, tidak berfokus dalam keterlibatan pengguna [8]. Hal tersebut menjadi penting karena pengguna akhir dari sebuah sistem adalah pengguna itu sendiri, sehingga perlu melibatkan pengguna akhir dalam pengembangan sebuah sistem. Menurut salah satu asosisasi antarmuka pengguna menyatakan bahwa banyak waktu terbuang dalam penggunaan sistem dikarenakan engguna tidak dapat menemukan informasi yang diinginkan dan hal tersebut berdampak terhadap penurunan produktivitas sehingga dapat meningkatkan frustasi [9].

Musyawarah Guru Bimbingan dan Konseling (MGBK) SMA Kota Malang telah dilaksanakan sejak tahun 2017. Seiring berjalannya waktu MGBK SMA Kota Malang memiliki keinginan untuk memberikan 
Jurnal TEKNOINFO, Vol. 16, No. 1, 2022, 138-143, ISSN: 2615-224X

kontribusi lebih khususnya bagi siswa/i SMA di Kota Malang. Namun hal tersebut terkendala keterbatasan sumber daya, baik dari sisi sumber daya manusia serta biaya operasional untuk mempubikasikan kegiatan, berita dan informasi terkini serta untuk proses melayani konseling siswa/i SMA/MA seluruh area Kota Malang akan menghabiskan banyak sumber daya jika dilakukan secara konvensional. Oleh karena itu MGBK SMA Kota Malang memerlukan media komunikasi yang juga berfungsi sebagai media publikasi kegiatan, berita, kerjasama dan untuk melakukan konseling untuk meningkatkan efisiensi dan efektivitas kegiatan dari MGBK SMA Kota Malang yaitu dengan menggunakan portal website.

Berdasarkan latar belakang diatas, maka dalam penelitian ini menggunakan metode User Centered Design (UCD) dalam proses perancangan portal website MGBK SMA Kota Malang karena lebih berfokus kepada pengguna sebagai pusat dari proses pengembangan portal website yang memandu dalam pembuatan desain dan usability.

\section{Metode Penelitian}

Pada penelitian ini menggunakan metodologi penelitian User Centered Design (UCD) yang mengacu pada ISO 9241-210 tahun 2010. Pada dokumen tersebut menyatakan bahwa UCD merupakan metode yang digunakan dalam perancangan dan pengembangan sistem yang bertujuan untuk menyesuaikan sistem dengan kebutuhan pengguna, karena dalam pengembangannya melibatkan pengguna secara langsung [10]. Adapun detail langkah-langkah dalam penelitian ini mengacu pada [11] yang secara detail akan dijelaskan pada paragraf di bawah ini.

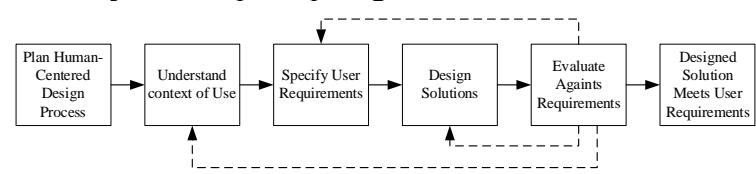

Gambar 1. Tahapan User Centered Design

\section{Plan Human-Centered Design Process}

Pada tahapan ini dilakukan penyusunan perencanaan yang akan dilakukan untuk sebagai tahap awal sebelum masuk pada tahap selanjutnya pada metode UCD [12]. Pada tahap plan humancentered design process dilakukan proses wawancara dan observasi [13]. Proses wawancara dilakukan untuk memahami kebutuhan data terkait dengan pembuatan antarmuka dan berfungsi untuk mengetahui gambaran kondisi saat ini. Proses wawancara dilakukan kepada Ketua MGBK SMA/MA Kota Malang.

Dari hasil wawancara didapatkan bahwa MGBK SMA/MA Kota Malang selama ini belum memiliki website dan prosesnya selama ini dilakukan secara manual. Oleh karena itu prosesnya cenderung lama dan memakan banyak biaya operasional, dan cakupan area layanan tidak luas karena keterbatasan wilayah dan jarak. Harapannya kedepan MGBK SMA/MA Kota Malang memiliki website sendiri yang secara detail terdapat pada tabel 1 di bawah ini.

Tabel 1. Hasil Wawancara \& Observasi

\begin{tabular}{|c|c|c|}
\hline Pertanyaan & $\begin{array}{c}\text { Kondisi saat } \\
\text { ini }\end{array}$ & Harapan \\
\hline $\begin{array}{l}\text { Bagaimana } \\
\text { selama ini } \\
\text { proses } \\
\text { penyampaian } \\
\text { berita } \\
\text { kegiatan } \\
\text { MGBK } \\
\text { SMA/MA } \\
\text { Kota } \\
\text { Malang? }\end{array}$ & $\begin{array}{l}\text { Pembagian } \\
\text { berita hanya } \\
\text { melalui grup } \\
\text { Whatsapp } \\
\text { Grup saja, } \\
\text { seringkali } \\
\text { tidak dapat } \\
\text { diketahui } \\
\text { pihak diluar } \\
\text { Whatsapp } \\
\text { Grup }\end{array}$ & $\begin{array}{l}\text { MGBK } \\
\text { SMA/MA Kota } \\
\text { Malang } \\
\text { memiliki portal } \\
\text { website sendiri } \\
\text { untuk } \\
\text { menunjang } \\
\text { publikasi } \\
\text { kegiatan }\end{array}$ \\
\hline $\begin{array}{l}\text { Bagaimana } \\
\text { proses } \\
\text { pelaksanaan } \\
\text { konsultasi? }\end{array}$ & $\begin{array}{l}\text { Proses } \\
\text { dilakukan oleh } \\
\text { masing- } \\
\text { masing guru } \\
\text { BK di masing- } \\
\text { masing } \\
\text { sekolah }\end{array}$ & $\begin{array}{l}\text { Terdapat } \\
\text { platform untuk } \\
\text { memungkinkan } \\
\text { konsultasi } \\
\text { secara daring, } \\
\text { untuk } \\
\text { memudahkan } \\
\text { proses } \\
\text { konsultasi dan } \\
\text { keterjangkauan }\end{array}$ \\
\hline
\end{tabular}

\section{Understand Context of Use}

Tahap ini berfungsi untuk mengetahui siapa saja pengguna akhir yang akan menggunakan portal website MGBK SMA/MA Kota Malang dan mengerti karakteristik penggunanya. Pada tahap ini dibagi menjadi dua proses yaitu proses identifikasi pengguna dan karakteristik pengguna [14].

\section{Identifikasi Pengguna}

Hasil identifikasi pengguna yang telah dilakukan sebelumnya terdapat pada tabel 2 berikut.

Tabel 2. Identifikasi Pengguna

\begin{tabular}{|l|l|}
\hline Pengguna & \multicolumn{1}{|c|}{ Deskripsi } \\
\hline $\begin{array}{l}\text { Administra } \\
\text { tor }\end{array}$ & $\begin{array}{l}\text { Pengelola portal website yang } \\
\text { berfungsi mengelola seluruh data } \\
\text { pengguna, konten website. }\end{array}$ \\
\hline Guru BK & $\begin{array}{l}\text { Memberikan informasi berupa } \\
\text { berita, acara, konseling, dan file }\end{array}$ \\
\hline Pengguna & $\begin{array}{l}\text { Mengakses portal website untuk } \\
\text { melihat berita, konseling, dan file }\end{array}$ \\
\hline
\end{tabular}

\section{Karakter Pengguna}

Pada tahap identifikasi pengguna yang telah dilakukan sebelumnya, selanjutnya adalah memahami karakter dari pengguna. Karakter pengguna pada portal website MGBK SMA/ MA Kota Malang terdapat pada tabel 3 berikut. 


\begin{tabular}{|c|c|}
\multicolumn{2}{c|}{ Tabel 3. Karakter Pengguna } \\
\hline Jenis & Keterangan \\
\hline Usia & Siswa: 15-18 tahun \\
& $\begin{array}{c}\text { Guru BK: 30-55 tahun } \\
\text { Administrator: 30-55 tahun }\end{array}$ \\
\hline Literasi & $\begin{array}{c}\text { Sebagian besar pengguna portal } \\
\text { website memiliki pengetahuan } \\
\text { Komputer }\end{array}$ \\
$\begin{array}{c}\text { pengunaan komputer dan } \\
\text { internet }\end{array}$ \\
\hline
\end{tabular}

Specify User Requirements

Tahap ini bertujuan untuk memahami kebutuhan pengguna secara spesifik. Adapun cara yang dilakukan adalah mewawancarai pengguna sehingga didapatkan hasil akhir kebutuhan pengguna yang terdapat pada tabel 4 berikut.

Tabel 4. Kebutuhan Pengguna

\begin{tabular}{|l|l|}
\hline Pengguna & \multicolumn{1}{|c|}{ Kebutuhan } \\
\hline \multirow{5}{*}{ Pengguna } & $\begin{array}{l}\text { 1. Melihat halaman home } \\
\text { 2. Melihat halaman berita } \\
\text { 3. Melihat halaman acara } \\
\text { 4. Melihat halaman konseling } \\
\text { 5. Melihat halaman kerjasama } \\
\text { 6. Melihat dan mengunduh file pada } \\
\text { halaman download } \\
\text { 7. Melihat halaman tentang }\end{array}$ \\
\hline \multirow{5}{*}{ Guru BK } & $\begin{array}{l}\text { 1. Registrasi pada portal website } \\
\text { 2. Login ke dalam portal website } \\
\text { 3. Mengunggah berita } \\
\text { 4. Mengunggah acara } \\
\text { 5. Mengunggah nomor pada } \\
\text { halaman konseling } \\
\text { 6. Mengunggah kerjasama } \\
\text { 7. Mengunggah file }\end{array}$ \\
\hline 1. Verifikasi akun Guru BK \\
2. Mengelola berita \\
3. Mengelola acara \\
4. Mengelola nomor halaman \\
konseling \\
5. Mengelola kerjasama \\
6. Mengelola file download
\end{tabular}

\section{Design Solutions}

Tahap ini berfungsi untuk merancang serta melakukan implementasi desain yang telah dirancang. Adapun fase dalam tahap ini adalah pembautan user flow dan pembuatan mock-up sistem yang akan dijelaskan pada poin berikutnya.

\section{Pembuatan User Flow}

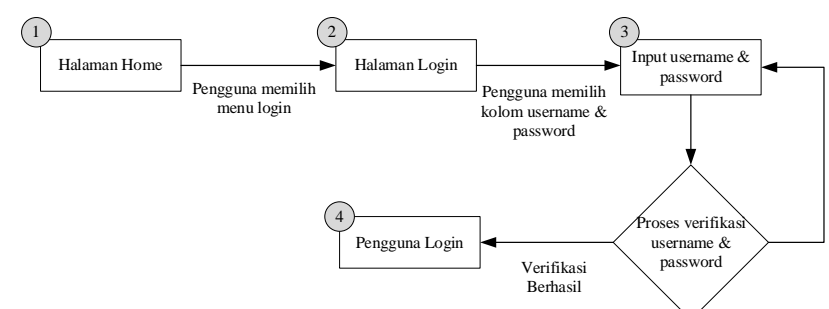

Gambar 2. User Flow Halaman Login

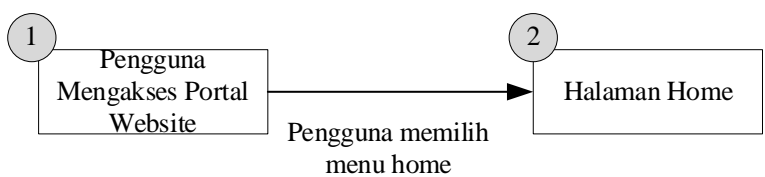

Gambar 3. User Flow Halaman Home

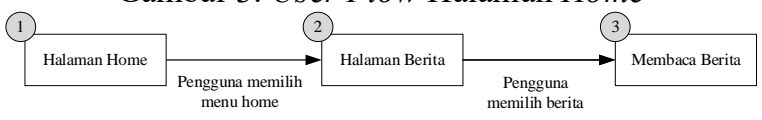

Gambar 4. User Flow Halaman Berita

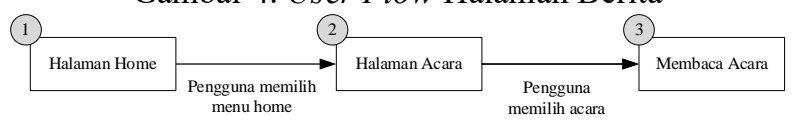

Gambar 5. User Flow Halaman Acara

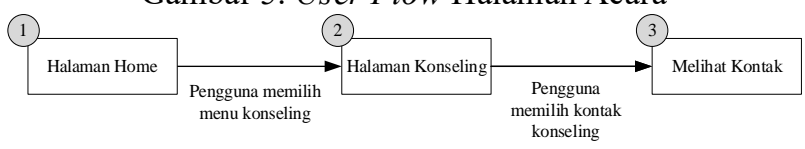

Gambar 6. User Flow Halaman Konseling

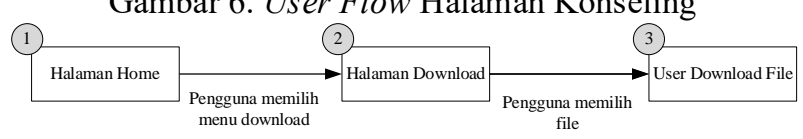

Gambar 7. User Flow Halaman Download

\section{Pembuatan Mock-up Portal Website}

Pada penelitian ini mock-up digunakan sebagai rancangan awal dari portal website yang akan dibuat. Dalam pembuatan mock-up ini menggunakan alat bantu Microsoft Visio. Adapun mock-up sistem yang dibuat terdapat pada gambar berikut.
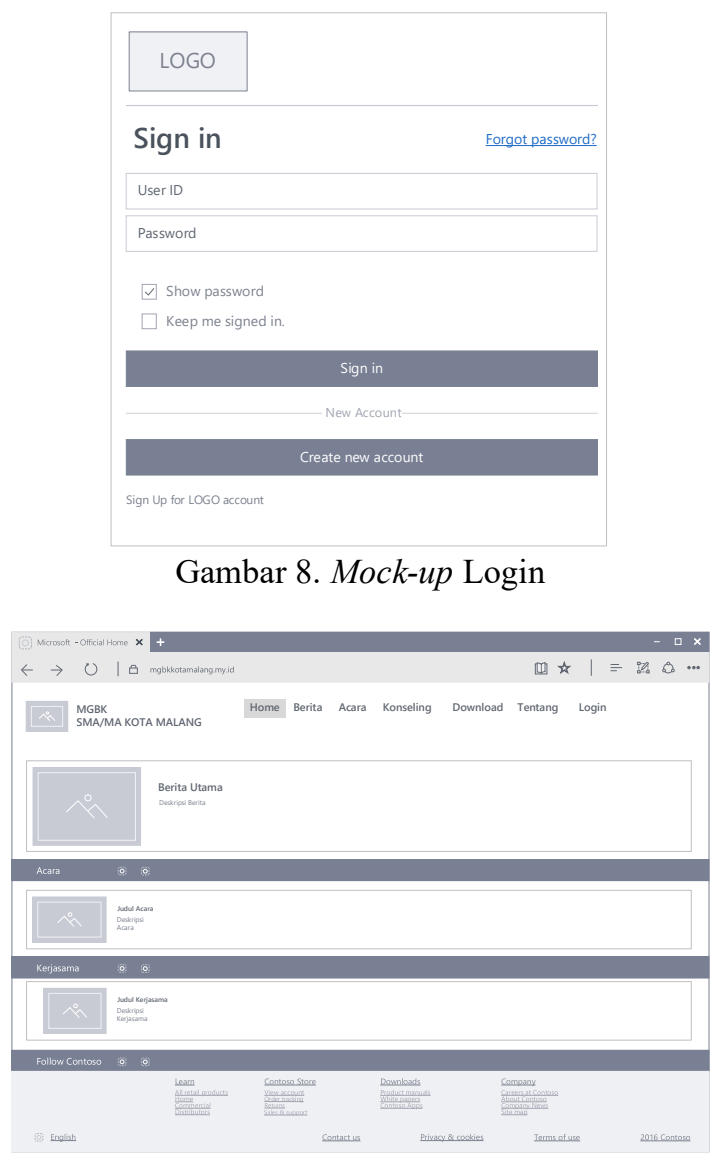

Gambar 9. Mock-up Halaman Home 
Jurnal TEKNOINFO, Vol. 16, No. 1, 2022, 138-143, ISSN: 2615-224X

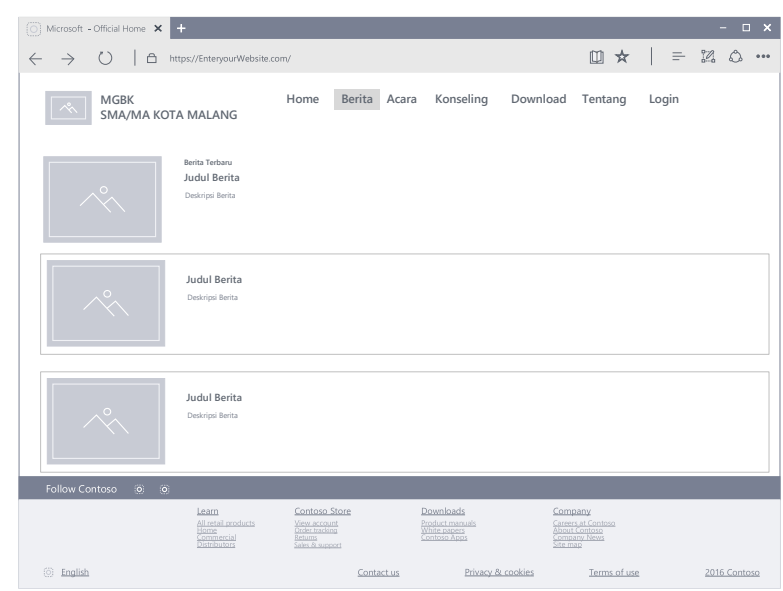

Gambar 10. Mock-up Halaman Berita

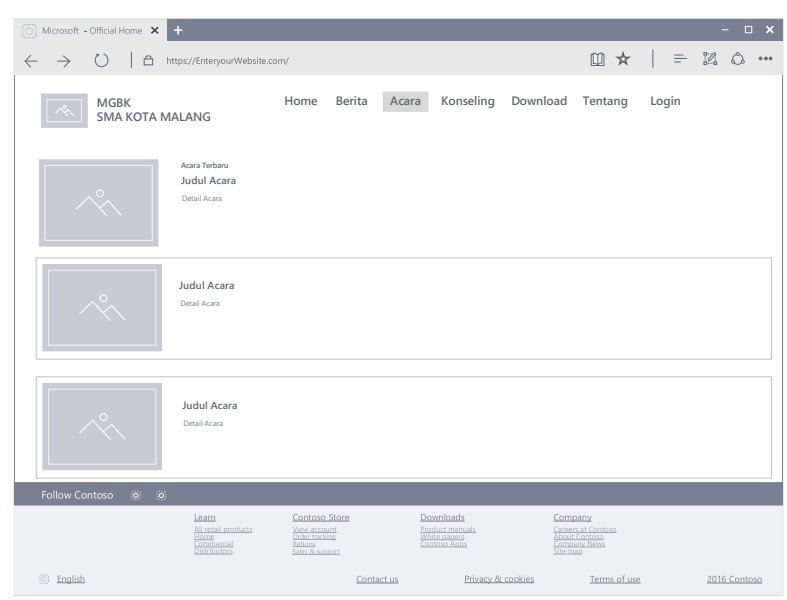

Gambar 11. Mock-up Halaman Acara

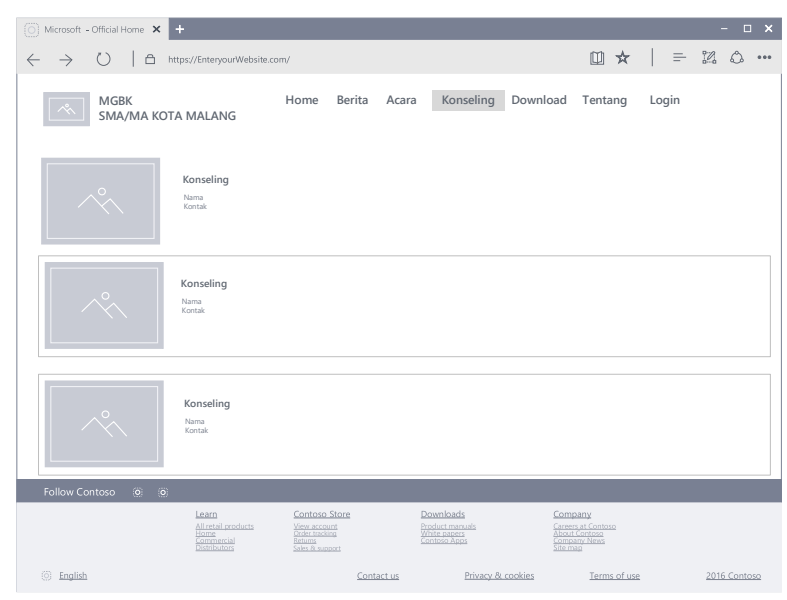

Gambar 13. Mock-up Halaman Konseling

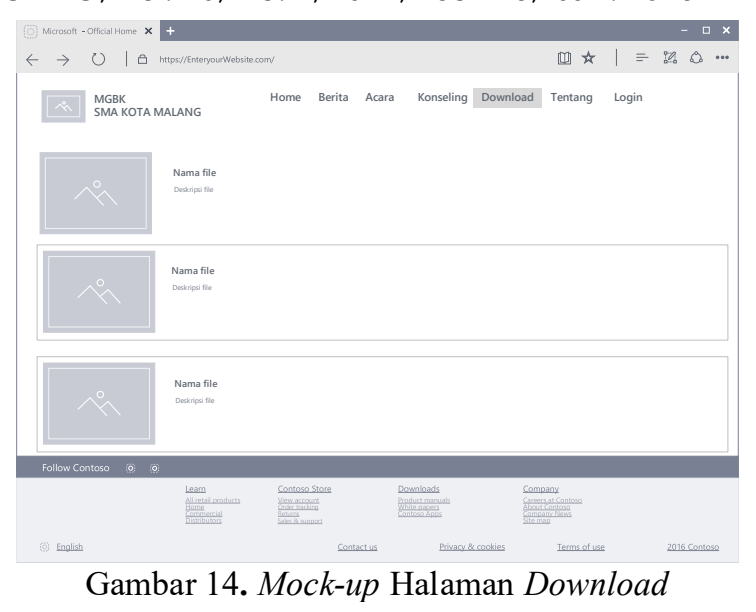

\section{Evaluate Againts Requirements}

Pada tahap ini akan dilakukan pengujian dari mockup sistem yang telah dibuat. Adapun pengujian yang dilakukan adalah Usability Testing.

\section{Usability Testing}

Pengujian usability testing merupakan metode untuk mengukur fungsionalitas dari sebuah sistemz [15], salah satunya adalah Hallway Testing [11]. Adapun langkah yang dilakukan dalam melakukan Hallway Testing yaitu menyusun beberapa skenario untuk menguji fitur sistem dan di uji coba kan kepada beberapa pengguna, secara umum skenario pengujian usability testing terdapat pada tabel di bawah ini.

Tabel 5. Skenario Pengujian

\begin{tabular}{|c|c|l|}
\hline No. & Nama Mockup & \multicolumn{1}{|c|}{ Skenario } \\
\hline 1 & Login & $\begin{array}{l}\text { Pengguna berhasil login ke } \\
\text { dalam sistem menggunakan } \\
\text { username dan password yang } \\
\text { telah diberikan }\end{array}$ \\
\hline 2 & Beranda & $\begin{array}{l}\text { Pengguna dapat mengakses } \\
\text { halaman beranda pada portal } \\
\text { website }\end{array}$ \\
\hline 3 & Berita & $\begin{array}{l}\text { Pengguna dapat mengakses } \\
\text { halaman berita pada portal } \\
\text { website }\end{array}$ \\
\hline 4 & Konseling & $\begin{array}{l}\text { Pengguna dapat mengakses } \\
\text { halaman konseling pada } \\
\text { portal website dan membuka } \\
\text { kontak Guru BK yang } \\
\text { terdapat pada halaman } \\
\text { konseling }\end{array}$ \\
\hline 5 & Download & $\begin{array}{l}\text { Pengguna dapat mengakses } \\
\text { halaman download pada } \\
\text { portal website dan } \\
\text { mengunduh file yang terdapat } \\
\text { pada halaman download }\end{array}$ \\
\hline
\end{tabular}

\section{HASIL DAN PEMBAHASAN}

Designed Solution Meets User Requirements 
Jurnal TEKNOINFO, Vol. 16, No. 1, 2022, 138-143, ISSN: 2615-224X

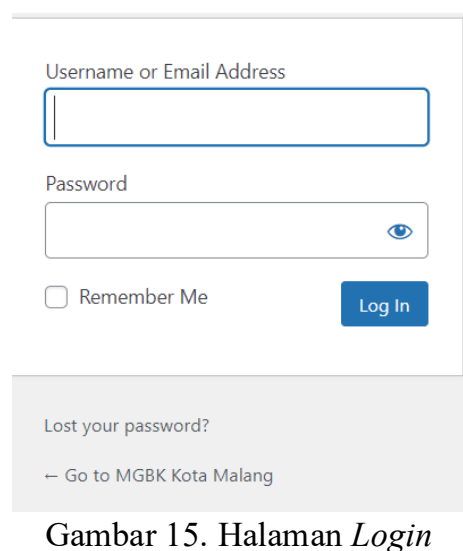

Gambar 15. Halaman Login

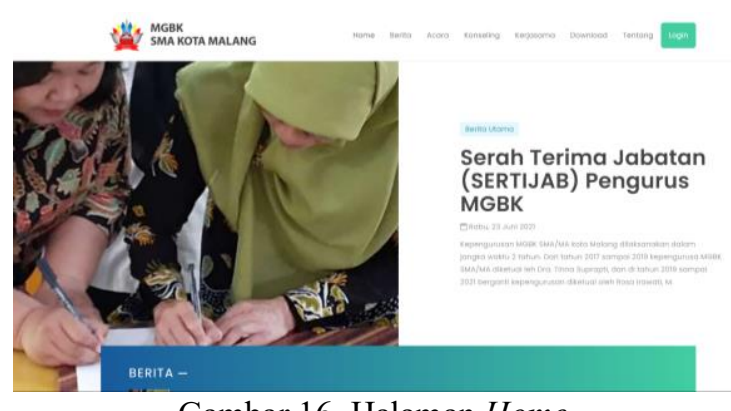

Gambar 16. Halaman Home
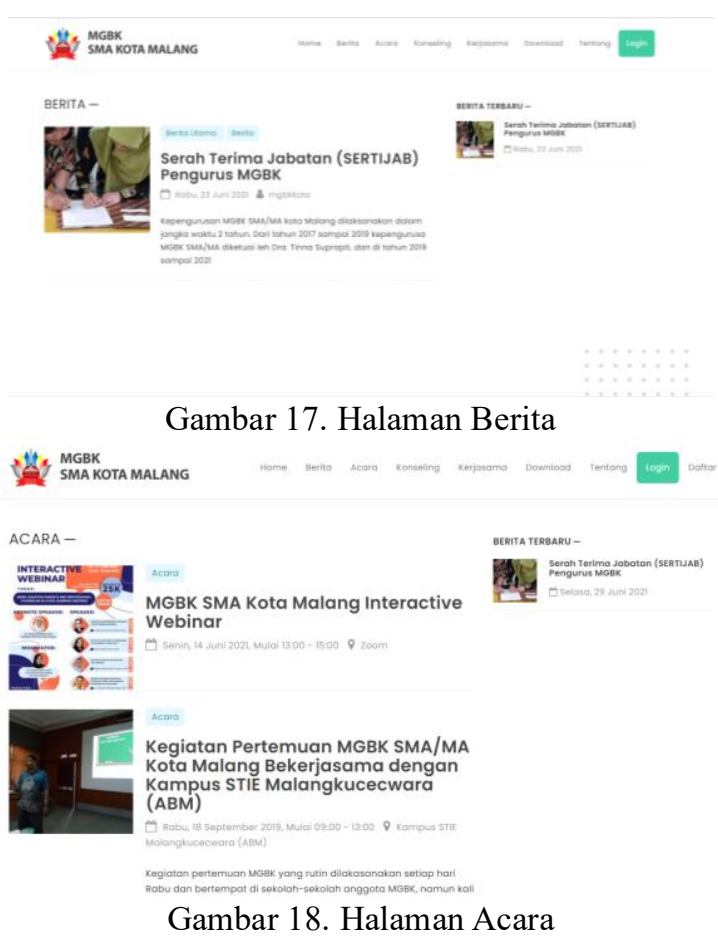
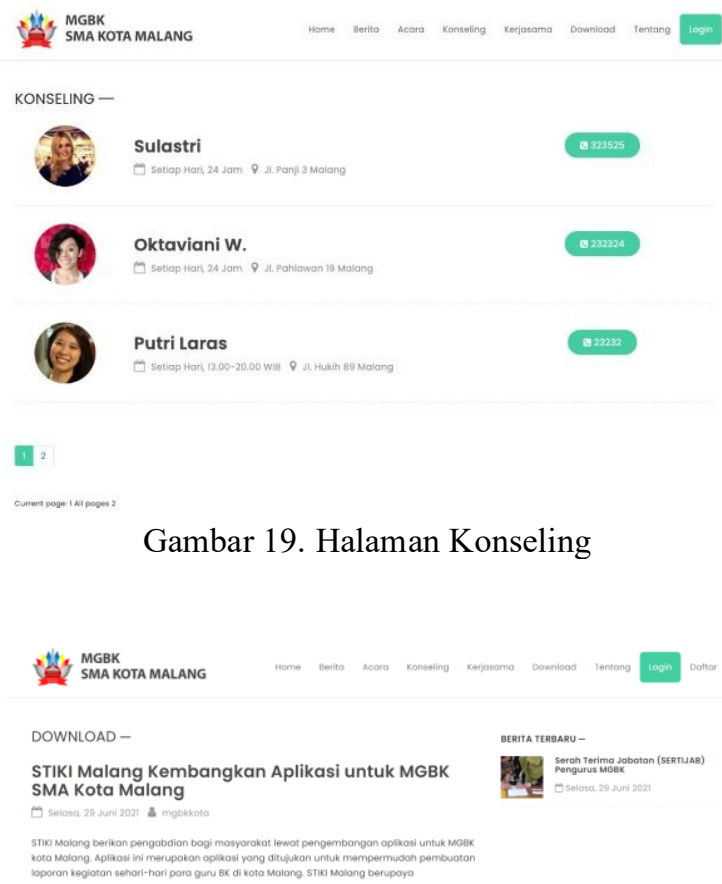

Gambar 20. Halaman Download

\section{Hasil Usability Testing}

Pengujian usability dilakukan kepada lima pengguna portal website. Adapun hasil pengujian usability testing terdapat pada tabel berikut.

\begin{tabular}{|c|c|c|c|c|c|}
\multicolumn{7}{c|}{ Tabel 6. Hasil Pengujian } \\
\hline \multirow{2}{*}{ Tester } & \multicolumn{5}{c|}{ Fitur } \\
\cline { 2 - 6 } & $\begin{array}{c}\text { Log } \\
\text { in }\end{array}$ & $\begin{array}{c}\text { Bera } \\
\text { nda }\end{array}$ & Berita & $\begin{array}{c}\text { Konsel } \\
\text { ing }\end{array}$ & $\begin{array}{c}\text { Downl } \\
\text { oad }\end{array}$ \\
\hline User 1 & OK & OK & OK & OK & OK \\
\hline User 2 & OK & OK & OK & OK & OK \\
\hline User 3 & OK & OK & OK & OK & OK \\
\hline User 4 & OK & OK & OK & OK & OK \\
\hline User 5 & OK & OK & OK & OK & OK \\
\hline
\end{tabular}

Dari hasil pengujian diatas dapat disimpulkan bahwa mock up yang dibuat dapat berjalan sesuai dengan skenario yang dibuat sebelumnya.

\section{KESIMPULAN DAN SARAN}

Dari hasil penelitian diatas, dapat disimpulkan bahwa dengan menerapkan user-centered design pada proses perancangan dan pembuatan portal website MGBK SMA/MA Kota Malang memiliki tingkat fungsionalitas $100 \%$. Dengan demikian dengan menerapkan metode user-centered design dapat dipergunakan untuk meningkatkan keberhasilan sebuah sistem.

Saran bagi penelitian selanjutnya adalah dalam tahap evaluate againts requirements dapat menggunakan pendekatan kuantitatif dengan menggunakan Delone and Mclean IS Success Model seperti kualitas informasi, kualitas sistem, dan kualitas layanan. 


\section{Daftar Pustaka}

[1]

B. Wibowo, K. Adi, and E. Sediono, "PENGEMBANGAN DAN EVALUASI SISTEM INFORMASI DI INSTALASI GIZI RSJ PROF DR SOEROJO MAGELANG," $J$. Teknoinfo, vol. 15, no. 1, p. 1, Jan. 2021.

[2] N. M. Widnyani et al., "Penerapan Transformasi Digital Pada Ukm Selama Pandemi," vol. 6, no. 1, pp. 79-87, 2021.

[3] R. Oktavenus, “Analisis Pengaruh Transformasi Digital dan Pola Perilaku Konsumen Terhadap Perubahan Bisnis Model Perusahaan di Indonesia," J. Manaj. Bisnis dan Kewirausahaan, vol. 3, no. 5, p. 44, 2019.

[4] L. Y. Siregar and M. I. P. Nasution, "Perkembangan Teknologi Informasi Terhadap Peningkatan Bisnis Online," HIRARKI J. Ilm. Manaj. dan Bisnis, vol. 02, no. 01, pp. 71-75, 2020.

[5] A. Tirtana, A. Zulkarnain, B. K. Kristanto, S. Suhendra, and M. A. Hamzah, "Rancang Bangun Aplikasi E-Commerce Untuk Meningkatkan Pendapatan UMKM," J. Ilm. Teknol. Inf. Asia, vol. 14, no. 2, p. 101, 2020.

[6] T. K. Ahsyar, A. Jakawendra, and Syaifullah Syaifullah, "Analisa Usability Website Berita Online Menggunakan Metode User Centered Design," J. Ilm. Rekayasa ..., vol. 6, no. 2, pp. 165-172, 2020.

[7] P. Tantri Fajarini, N. K. Ayu Wirdiani, and I. P. Arya Dharmaadi, "Evaluasi Portal Berita Online pada Aspek Usability Menggunakan Heurtistic Evaluation dan Think Aloud," J. Teknol. Inf. dan Ilmu Komput., vol. 7, no. 5, p. 905, 2020.

[8] Y. Sugandi, "Pengembangan Sistem Aplikasi Portal Informasi Perguruan Tinggi di Indonesia Berbasis Website," J. Pengemb. Teknol. Inf. dan Ilmu Komput., vol. 2, no. 12, pp. 6169-6175,
2018.

[9] I. S. Yatana Saputri, M. Fadhli, and I. Surya, "Penerapan Metode UCD (User Centered Design) Pada E-Commerce Putri Intan Shop Berbasis Web," J. Nas. Teknol. dan Sist. Inf., vol. 3, no. 2, pp. 269-278, 2017.

[10] D. L. Kaligis and R. R. Fatri, "Pengembangan Tampilan Antarmuka Aplikasi Survei Berbasis Web Dengan Metode User Centered Design," JUST IT J. Sist. Informasi, Teknol. Inf. dan Komput., vol. 10, no. 2, p. 106, 2020.

[11] A. Zulkarnain, "Penerapan Mobile-First Design pada Antarmuka Website Profil Sekolah Menggunakan Metode Human-Centred Design (Studi Kasus: SMPN 21 Malang),” J. Ilm. Teknol. Inf. Asia, vol. 13, no. 2, pp. 125-136, 2019.

[12] S. Supardianto and A. B. Tampubolon, "Penerapan UCD (User Centered Design) Pada Perancangan Sistem Informasi Manajemen Aset TI Berbasis Web di Bid TIK Kepolisian Daerah Kepulauan Riau," J. Appl. Informatics Comput., vol. 4, no. 1, pp. 74-83, 2020.

[13] G. Karnawan, "Implementasi User Experience Menggunakan Metode Design Thinking Pada Prototype Aplikasi Cleanstic," J. Teknoinfo, vol. 15 , no. 1, p. 61, 2021.

[14] L. M. Kopf and J. Huh-Yoo, “A User-Centered Design Approach to Developing a Voice Monitoring System for Disorder Prevention," J. Voice, vol. 3200, 2020.

[15] N. A. Dewananto, H. Tolle, and H. M. Az-zahra, "Perancangan User Experience Menggunakan Metode Human Centered Design Pada Aplikasi Mobile Portal Berita Tabloidjubi," J. Pengemb. Teknol. Inf. dan Ilmu Komput. Univ. Brawijaya, vol. 3, no. 3, pp. 2916-2922, 2019. 